\title{
Chloroquine and COVID-19: A Light at the End of the Tunnel, or is it Another Train?
}

\author{
Mohamad Aljofan ${ }^{1 \star}$, Abduzhappar Gaipov ${ }^{1}$
}

${ }^{1}$ School of Medicine, Nazarbayev University, Nur-Sultan, KAZAKHSTAN
${ }^{\star}$ Corresponding Author: m.aljofan@gmail.com

Citation: Aljofan M, Gaipov A. Chloroquine and COVID-19: A Light at the End of the Tunnel, or is it Another Train?. Electron J Gen Med. 2020;17(4):em207. https://doi.org/10.29333/ejgm/7863

\begin{tabular}{ll}
\hline ARTICLE INFO & $\begin{array}{l}\text { ABSTRACT } \\
\text { Received: } 29 \text { Mar. } 2020\end{array} \quad \begin{array}{l}\text { Over the last a few decades, the world has faced several viral disease outbreaks including Hendra, Nipah, severe } \\
\text { acute respiratory syndrome (SARS), Influenza (H1N1), Middle East respiratory syndrome (MERS), Zika and most } \\
\text { recently coronavirus disease 2019 (COVID-19). The economical and health impacts of the outbreaks were limited } \\
\text { to certain affected areas only, but the recent outbreak of COVID-19 seems to have a global impact on human } \\
\text { health, health resources and global economy. }\end{array}$
\end{tabular}

Keywords: COVID-19

Over the last a few decades, the world has faced several viral disease outbreaks including Hendra, Nipah, severe acute respiratory syndrome (SARS), Influenza (H1N1), Middle East respiratory syndrome (MERS), Zika and most recently coronavirus disease 2019 (COVID-19). The economical and health impacts of the outbreaks were limited to certain affected areas only, but the recent outbreak of COVID-19 seems to have a global impact on human health, health resources and global economy.

COVID-19 is a member of the species of the coronavirus family that cause severe acute respiratory syndrome-related diseases. COVID-19 is a zoonotic virus that belongs to the Coronavirus family, which belongs to the Coronaviridae suborder (1). Currently, there is no vaccine or treatment for COVID-19. The high infectivity and lethality of COVID-19 necessitated its classification as a biological safety level 4 (BSL4) pathogen. Since its emergence in late 2019 in Wuhan-China, COVID-19 infected approximately 678,905 including 31,771 deaths worldwide (as of March 29 2020) (2).

There is an extensive effort across the globe to develop novel coronavirus vaccine or antiviral treatment to tackle the spread of the mysterious and previously unknown virus infection. While we remain hopeful that the current effort will be fruitful, we speculate that at best an effective treatment may not be available before yearend. Nonetheless, one of the most promising drug candidates is chloroquine, an FDA approved therapy for the treatment and prevention of malaria infection, which has received an international attention for its potential effect as an antiviral against COVID-19. The Chinese National Centre for Biotechnology Development announced that the results of 100 patients treated with chloroquine showed improved CT scan of lung, reduction in fever and a shorter recovery time compared with other groups (3). Also, a study from France that used the drug in a small number of infected patients claimed to have positive clinical outcomes (4).
The use of chloroquine as an antiviral is not an entirely new phenomenal. Almost four decades ago, Coombs and colleagues claimed that the use of chloroquine significantly reduced viral yields of Sindbis virus in BHK cells (5). Similarly, the drug was tested in vitro against SARS virus by Vincent et al., 2005, which claimed that chloroquine shows potent antiviral activity against SARS virus (6). The authors claimed that the antiviral activity of chloroquine is partly due to its effect in increasing endosomal $\mathrm{pH}$ and its ability to glycosylate the viral entry receptor, angiotensin converting enzyme. Also, in 2013 Yan et al, reported that chloroquine is highly effective in treating avian influenza A H5N1 virus in animals (7). Furthermore, in collaboration with Weil Cornell Medical College, we showed that chloroquine was able to inhibit Nipah and Hendra virus infections in vitro (8). However, the use of chloroquine against Nipah infected ferrets, did not prevent the disease (8).

In conclusion, despite the fact that the drug has been in use for more than half a century and was shown in vitro to have potent antiviral activity against several viruses including COVID-19, chloroquine failed to treat several viral infections in animal and human studies. Therefore, in the absence of randomized control clinical trials, we should be careful not to draw early conclusions, as the light we see may turnout to be another train.

\section{REFERENCES}

1. Gorbalenya A, Baker S, Baric R, de Groot R, Drosten C, Gulyaeva A, et al. The species Severe acute respiratory syndrome-related coronavirus: classifying 2019-nCoV and naming it SARS-CoV-2. Nature Microbiology. 2020. 
2. Worldmeter. Coronavirus Cases_ Statistics and Charts Worldometer 2020 [cited 2020 March 29]. Available at: https://www.worldometers.info/coronavirus/

3. Gao J, Tian Z, Yang X. Breakthrough: Chloroquine phosphate has shown apparent efficacy in treatment of COVID-19 associated pneumonia in clinical studies. Bioscience trends. 2020. https://doi.org/10.5582/ bst.2020.01047 PMid:32074550

4. Colson P, Rolain J-M, Lagier J-C, Brouqui P, Raoult D. Chloroquine and hydroxychloroquine as available weapons to fight COVID-19. Int J Antimicrob Agents. 2020;105932. https://doi.org/10.1016/j.ijantimicag.2020. 105932 PMid:32145363

5. Coombs K, Mann E, Edwards J, Brown DT. Effects of chloroquine and cytochalasin $B$ on the infection of cells by Sindbis virus and vesicular stomatitis virus. Journal of Virology. 1981;37(3):1060-5. https://doi.org/10.1128/ JVI.37.3.1060-1065.1981 PMid:6262524 PMCid:PMC171103
6. Vincent MJ, Bergeron E, Benjannet S, Erickson BR, Rollin PE, Ksiazek TG, et al. Chloroquine is a potent inhibitor of SARS coronavirus infection and spread. Virology journal. 2005;2(1):69. https://doi.org/10.1186/1743-422X-2-69 PMid:16115318 PMCid:PMC1232869

7. Yan Y, Zou Z, Sun Y, Li X, Xu K-F, Wei Y, et al. Anti-malaria drug chloroquine is highly effective in treating avian influenza A H5N1 virus infection in an animal model. Cell research. 2013;23(2):300-2. https://doi.org/10.1038/ cr.2012.165 PMid:23208422 PMCid:PMC3567830

8. Porotto M, Orefice G, Yokoyama CC, Mungall BA, Realubit R, Sganga ML, et al. Simulating henipavirus multicycle replication in a screening assay leads to identification of a promising candidate for therapy. Journal of virology. 2009;83(10):5148-55. https://doi.org/10.1128/JVI.00164-09 PMid:19264786 PMCid:PMC2682105 